\title{
Pengaruh Kualitas Produk Wisata Umrah terhadap Minat Kunjungan Wisatawan Lansia di Annisa Travel Jakarta
}

\author{
Yulianandaris $^{1}$, I Made Adhi Gunadi ${ }^{2}$, Meizar Rusli ${ }^{3}$ \\ Fakultas Pariwisata Universitas Pancasila, Srengseng Sawah, Jagakarsa, Jakarta Selatan 12460, Indonesia \\ ${ }^{1}$ yulianandaris11@gmail.com ${ }^{2}$ made.gunadi@univpancasila.ac.id ${ }^{*}, 08161976441{ }^{3}$ meizar@univpancasila.ac.id
}

\section{ARTICLE INFO}

Article history:

Received: September 15, 2020

Reviewed: October 23, 2020

Accepted: November 16, 2020

Published: December 21, 2020

Keyword: tourism product, umrah pilgrimage, visit intention, elderly tourist

Kata kunci: kualitas produk, wisata umrah, minat kunjungan, wisatawan lansia

\section{ABSTRACT}

The interest and trend of Umrah pilgrimage combined with tourism activities continues to increase, making competition among the travel agent industry more competitive. In the Umrah tourism provider, this means very important to pay attention to the needs, wants and fulfill customer expectations by providing better product quality. This study aims to see the effect of the quality of tourism products on the main market segment in Umrah tourism which is the elderly tourists to their intention to visit and do Umrah. The research is used quantitative research methods. Data were collected from 51 respondents using questionnaire and analysis using simple linear regression analysis. The results showed that there were dimensions of the tourism product qualities that had an effect and had no effect on intention to visit. The dimensions of public facilities, human resources and accessibility are significantly influence intention to visit, whilst those classified as non-influential dimensions are the dimensions of attraction, cleanliness, information and services.

\section{ABSTRAK}

Minat dan tren perjalanan ibadah umrah yang dikemas bersama kegiatan wisata terus meningkat, membuat persaingan dalam industri wisata semakin kompetitif. Bagi pelaku wisata umrah, artinya kian penting untuk memperhatikan kebutuhan dan keinginan serta memenuhi harapan pelanggan dengan cara memberikan kualitas produk yang lebih baik. Penelitian ini bertujuan untuk melihat pengaruh kualitas produk wisata terhadap minat pasar utama wisata umrah yaitu wisatawan lansia untuk berkunjung melakukan ibadah umrah. Metode penelitian yang digunakan adalah metode penelitian kuantitatif. Data dikumpulkan dari 51 responden dengan menggunakan kuesioner dan analisis data menggunakan regresi linear sederhana. Hasil penelitian menunjukkan bahwa terdapat dimensi kualitas produk wisata yang berpengaruh dan tidak berpengaruh terhadap minat kunjungan. Dimensi yang berpengaruh adalah fasilitas umum, sumber daya manusia dan aksesibilitas. Sedangkan dimensi yang tidak berpengaruh adalah dimensi atraksi, kebersihan, informasi dan pelayanan. 


\section{Pendahuluan}

Wisata yang fenomenal dan terus berkembang menjadi segmen yang penting bagi pariwisata adalah wisata religi seperti wisata umrah. Perjalanan agama dan spiritual dalam Islam dapat dibagi menjadi tiga bentuk kegiatan. Kegiatan pertama adalah melakukan haji, perjalanan spiritual kedua adalah Rihla, aktivitas ketiga disebut Ziyara.

Umrah adalah ziarah non-wajib ke Mekkah yang dapat dilakukan oleh umat Islam sepanjang tahun (Hassan et.al. 2015).

Banyaknya aktivitas perjalanan ibadah umrah yang dilakukan wisatawan, membuat persaingan dalam industri perjalanan wisata semakin ketat, sehingga setiap industri penting untuk memperhatikan kebutuhan dan keinginan serta memenuhi harapan pelanggan dengan cara memberikan kualitas produk yang lebih baik. Produk yang memiliki kualitas yang kuat dengan perbedaan dan keunggulan yang dimiliki dibanding produk pesaing dapat meningkatkan minat kunjungan. Minat akan muncul dalam diri seseorang. Merasa tertarik, terdorong terhadap apa yang diinginkan dan berencana untuk membeli produk yang ditawarkan.

Annisa Travel merupakan salah perusahaan swasta yang bergerak di bidang jasa perjalanan. Salah satu fokus utama layanannya adalah paket umrah. Annisa Travel memiliki kekhasan sebagai biro perjalanan umrah yang cukup banyak diminati oleh wisatawan. Hal ini dapat dilihat pada data kunjungan wisatawan yang menggunakan produk Annisa Travel di lima tahun terakhir.

Berdasarkan pada data tersebut, dapat dilihat bahwa jumlah kunjungan pada wisata umrah lebih unggul dibandingkan dengan produk wisata haji serta MICE and event.
Tabel 1.1 Data konsumen Annisa Travel

\begin{tabular}{|c|c|c|}
\hline $\begin{array}{c}\text { Produk } \\
\text { wisata }\end{array}$ & Tahun & $\begin{array}{c}\text { Jumlah } \\
\text { Kunjungan }\end{array}$ \\
\hline Haji & $2015-$ & 336 wisatawan \\
2019 & $2015-$ & 2.155 \\
Umrah & 2019 & wisatawan \\
\hline MICE and & $2015-$ & 1.646 \\
Event & 2019 & wisatawan \\
\hline
\end{tabular}

Pada produk wisata umrah Annisa Travel dalam pelaksanaanya banyak diminati oleh segmen wisatawan lansia, dimana para lansia memiliki karakter cenderung untuk mengisi waktu luang mereka dengan aktivitas yang lebih bermanfaat, salah satunya dengan cara melakukan perjalanan wisata umrah untuk beribadah guna meningkatkan keimanan dan ketakwaan mereka serta mendekatkan diri kepada sang pencipta.

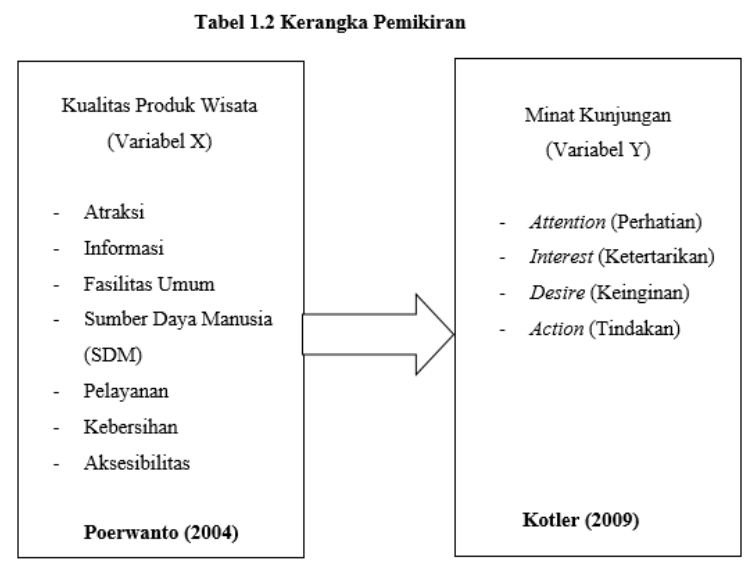

\section{Tinjauan Pustaka}

\section{Wisata Religi}

Pendit (2006 dalam Anwar et al. 2017) menjelaskan bahwa, wisata religi atau wisata pilgrim sedikit banyak berkaitan dengan, adat istiadat, agama dan kepercayaan umat atau kelompok dalam masyarakat. Wisata religi dianggap mampu meningkatkan karakter religiusitas melalui sejumlah peran sebagai berikut: 
- wisata religi berperan dalam meningkatkan religious practice

- wisata religi berperan dalam meningkatkan religious belief

- wisata religi berperan dalam meningkatkan religious knowledge

- wisata religi berperan dalam meningkatkan religious feeling

- wisata religi berperan dalam meningkatkan religious effect

Dalam Islam sendiri, perjalanan agama dan spiritual dapat dibagi menjadi tiga bentuk kegiatan. Kegiatan pertama adalah melakukan haji, yang merupakan salah satu dari lima rukun Islam dan merupakan dasar bagi praktik muslim. Kegiatan kedua adalah Rihla, perjalanan mencari pengetahuan, perdagangan, kesehatan atau penelitian. Aktivitas ketiga disebut Ziyara, yang mengharuskan seorang muslim untuk mengunjungi kuil, masjid, atau biara untuk pertumbuhan spiritual (Hassan et.al. 2015). Adapun manfaat dari wisata religi adalah untuk mengingat kematian dan menambah amal shaleh serta tujuan wisata religi mempunyai makna yang dapat dijadikan pedoman untuk menyampaikan syiear Islam di seluruh dunia, dijadikan sebagai pelajaran, untuk mengingat ke-Esaan Allah, mengajak dan menuntun (Amalina, 2017).

\section{Umrah}

Umrah berasal dari bahasa Arab yaitu I'tamara berarti berkunjung atau ziarah. Kata ini juga berarti meramaikan tanah suci Mekah yang di situ terletak Masjidil Haram dan di dalamnya terdapat Ka'bah. Namun demikian, umrah dalam konteks ibadah tidak sekedar berarti meramaikan, melainkan lebih dari itu, yaitu orang melaksanakannya dituntut agar dapat mengambil manfaat dari umrahnya, karena sebagaimana haji, aktivitas umrah merupakan refleksi dari pengalaman hamba-hamba Allah, yaitu Ibrahim As. dan putranya Ismail As.
Produk Wisata

Dalam berwisata, wisatawan menikmati berbagai produk pariwisata, dimana produk pariwisata tersebut merupakan gabungan dari berbagai produk barang maupun jasa yang ada di industry pariwisata.

Buhalis (2000) menyatakan bahwa atribut produk pariwisata diantaranya adalah attractions (atraksi wisata), amenities (fasilitas), accessibility (aksesibilitas), activities (aktivitas), available packages (ketersediaan paket), dan ancillary services (layanan tambahan). Sedangkan atribut produk pariwisata menurut Holloway, Humphreys dan Davidson (2009) yaitu attractions, amenities dan accessibility. Selain itu mereka menambahkan penjelasan bahwa "all destinations require adequate attractions, amenities and accessibility if they are to appeal to large numbers of tourists." Jika diterjemahkan yaitu semua destinasi memerlukan atraksi, amenitas dan aksesibilitas yang memadai apabila mereka ingin menarik jumlah wisatawan yang banyak.

Kualitas Produk Wisata

Menurut Kotler (1997), elemen produk terbagi dalam beberapa tingkatan, yaitu core benefit, basic product, expected product, augmented product, dan potential product.

Bodlender et.al (1991), menyatakan bahwa kualitas produk wisata adalah persepsi terhadap daya tarik wisata serta harapan atas kepuasan-kepuasan yang akan diperoleh dari atraksi wisata tersebut berakumulasi menjadi kekuatan yang besar untuk mendorong seseorang untuk menentukan pilihan atas destinasi wisata yang akan dikunjungi. Adapun dimensi kualitas produk wisata menurut Poerwanto (2004), ada 7 dimensi yaitu, atraksi, informasi, fasilitas umum, sumber daya manusia (SDM), pelayanan, kebersihan dan aksesibilitas. 
Minat Kunjungan

Minat berkunjung merupakan bentuk atau wujud dari minat berperilaku. Menurut Simamora (2002) secara teoritis minat berperilaku adalah suatu kecenderungan potensial untuk mengadakan reaksi (sikap mendahului perilaku). Minat berkunjung berarti konsumen (pengunjung) potensial yang pernah dan belum pernah dan yang sedang akan berkunjung pada suatu atraksi wisata. Minat merupakan kekuatan pendorong yang menyebabkan seseorang menaruh perhatian pada suatu objek. Dimensi minat wisatawan menurut (Kotler, 2009), menjelaskan mengenai teori AIDA yang terdiri dari, attention (perhatian), interest (ketertarikan), desire (keinginan), action (tindakan).

\section{Wisatawan Lansia}

Lanjut usia (lansia) merupakan periode akhir dari rentang kehidupan manusia. Lanjut usia (lansia) merupakan proses alami yang tidak dapat dihindarkan oleh setiap individu. Menurut World Health Organization (WHO) atau organisasi kesehatan dunia (dalam Mubarak, 2006), menyatakan bahwa lanjut usia meliputi usia pertengahan (45-59 tahun), lanjut usia (60-74 tahun), usia tua (75-90 tahun), dan usia sangat tua (di atas 90 tahun).

Menghadapi periode ini sebagian lansia melewati hidupnya bersama keluarga, ada juga yang hidup sendiri karena pasangan hidup mereka sudah meninggal atau juga tidak punya sanak saudara sama sekali. Melewati masa ini, lansia memiliki kesempatan untuk berkembang mencapai pribadi yang lebih baik dan semakin matang. Lansia masih dapat mengembangkan diri dan berkreasi sesuai dengan minat mereka. Lansia dapat melakukan sesuatu yang berarti untuk diri mereka sendiri dan orang lain (Sulandari et.al. 2009), salah satunya dengan melakukan wisata religi seperti umrah.

\section{Metodologi}

Desain penelitian yang digunakan adalah penelitian kuantitatif untuk menguji hipotesis yang telah ditetapkan. Sementara data dikumpulkan melalui survei kuesioner terhadap 51 responden. Lokasi penelitian yang di gunakan adalah Annisa Travel yang beralamat di Jl. Raya Lenteng Agung No. 8A, RT 05/RW 08, Lenteng Agung, Kecamatan Jagakarsa, Jakarta Selatan. Waktu untuk melaksanakan penelitian ini terhitung dari April - Juli 2020.

Data primer pada penelitian ini merupakan data yang langsung didapat dari pihak pertama. Sumber sekunder adalah sumber data yang diperoleh dengan cara membaca, mempelajari dan memahami melalui media lain yang bersumber dari literatur, buku-buku, serta dokumen.

Variabel

Variabel bebas (Variabel independen) dalam penelitian ini yaitu variable $\mathrm{X}$ yang digunakan adalah kualitas produk wisata menurut Poerwanto (2004). Sementara variabel terikat (Variabel Dependen) atau variabel Y yang digunakan adalah minat kunjungan menurut Kotler (2009).

\section{Hipotesis}

H1: Ha: Terdapat pengaruh variabel atraksi terhadap variabel minat kunjungan wisata umrah di Annisa Travel Jakarta

$\mathrm{H} 2$ : Ha: Terdapat pengaruh variabel informasi terhadap variabel minat kunjungan wisata umrah di Annisa Travel Jakarta

H3: Ha: Terdapat pengaruh variabel fasilitas umum terhadap variabel minat kunjungan wisata umrah di Annisa Travel Jakarta

H4: Ha: Terdapat pengaruh variabel sumber daya manusia (SDM) terhadap variabel minat kunjungan wisata umrah di Annisa Travel Jakarta 
H5: Ha: Terdapat pengaruh variabel pelayanan terhadap variabel minat kunjungan wisata umrah di Annisa Travel Jakarta

H6: Ha: Terdapat pengaruh variabel kebersihan terhadap variabel minat kunjungan wisata umrah di Annisa Travel Jakarta

H7: Ha: Terdapat pengaruh variabel aksesibilitas terhadap variabel minat kunjungan wisata umrah di Annisa Travel Jakarta

Tabel 3.1 Definisi Operasional Variabel

\begin{tabular}{|c|c|c|c|}
\hline $\begin{array}{l}\text { Variabel } \\
\text { Penelitian }\end{array}$ & Sub Variabel & Indikator & $\begin{array}{c}\text { Sumber } \\
\text { Data }\end{array}$ \\
\hline \multirow{8}{*}{$\begin{array}{c}\text { Kualitas Produk } \\
\text { Wisata }\end{array}$} & Atraksi & $\begin{array}{l}\text { Destinasi menarik } \\
\text { Pemandu wisata kompeten } \\
\text { Harga beragam } \\
\text { - Atraksi pendukumg baik }\end{array}$ & Wisatawan \\
\hline & Informasi & $\begin{array}{l}\text { - Jelas } \\
\text { - Lengkap } \\
\text { - Akurat } \\
\text { - Detail }\end{array}$ & Wisatawan \\
\hline & $\begin{array}{l}\text { Fasilitas } \\
\text { Unumm }\end{array}$ & $\begin{array}{l}\text { - Lengkap } \\
\text { - Nyaman } \\
\text { - Aman } \\
\text { - Bersih }\end{array}$ & Wisatawan \\
\hline & $\begin{array}{l}\text { Sumber Daya } \\
\text { Manusia } \\
\text { (SDM) }\end{array}$ & $\begin{array}{l}\text { - Kompeten } \\
\text { - Karyawan cukup } \\
\text { - Tepat } \\
\text { - Berpenampilan rapi } \\
\end{array}$ & Wisatawan \\
\hline & Pelayanan & $\begin{array}{l}\text { - Ramah } \\
\text { - Tamggap } \\
- \text { Santun } \\
- \text { Mampu menangani keluhan }\end{array}$ & Wisatawan \\
\hline & Kebersihan & $\begin{array}{l}\text { Hotel bersih } \\
\text { - Perlengkapan bersih } \\
-\quad \text { Transportasi bersih } \\
- \text { Restoran bersih } \\
\end{array}$ & Wisatawan \\
\hline & Aksesibilitas & $\begin{array}{l}\text { Mudah didapat } \\
\text { - Tersedia di banyak piliha cara } \\
\text { (channel) } \\
\text { - Lokasi strategis } \\
\text { - Ketersediann transportasi umum }\end{array}$ & Wisatawan \\
\hline & $\begin{array}{l}\text { Attention } \\
\text { (Perhatian) }\end{array}$ & $\begin{array}{l}\text { Harga pakat menarik perhatian } \\
\text { - Fasilitas paket menarik perhatian } \\
\text { - Pelayanan menarik perhatian }\end{array}$ & \\
\hline
\end{tabular}

\begin{tabular}{|c|c|c|c|}
\hline \multirow{4}{*}{$\begin{array}{c}\text { Minat } \\
\text { Kunjungan }\end{array}$} & & - Promo menarik perhatian & Wisatawan \\
\hline & $\begin{array}{c}\text { Interest } \\
\text { (Ketertarikan) }\end{array}$ & $\begin{array}{l}\text { Harga paket membuat tertarik } \\
\text { berkunjung } \\
\text { Fasilitas paket membuat tertarik } \\
\text { berkunjung } \\
\text { - Pelayanan yang diberikan membuat } \\
\text { tertarik berkunjung } \\
\text { - Promo membuat tertarik } \\
\text { berkunjung }\end{array}$ & Wisatawan \\
\hline & $\begin{array}{c}\text { Desire } \\
\text { (Keinginan) }\end{array}$ & $\begin{array}{l}\text { - Harga paket membuat ingin } \\
\text { berkunjung } \\
\text { - Fasilitas paket membuat ingin } \\
\text { berkunjung } \\
\text { - Pelayanan yang diberikan membuat } \\
\text { ingin berkunjung } \\
\text { - Promo membuat ingin berkunjung }\end{array}$ & Wisatawan \\
\hline & $\begin{array}{c}\text { Action } \\
\text { (Tindakan) }\end{array}$ & $\begin{array}{l}\text { Memesan paket umrah } \\
\text { Menyiapkan kebutuhan pribadi } \\
\text { untulk melaksankan umrah } \\
\text { Melakukan pemeriksaan kesehatan } \\
\text { sebelum umrah } \\
\text { Melakssanakan ibadah umrah }\end{array}$ & Wisatawan \\
\hline
\end{tabular}

Teknik pengambilan sampel yang digunakan menurut Sugiyono (2016) adalah teknik non-probability sampling dengan pendekatan purposive sampling. Calon responden harus memenuhi kriteria tertentu yaitu: responden yang sudah pernah menggunakan paket umrah
Annisa Travel; serta responden yang memiliki umur 45-59 tahun. Berdasarkan WHO, mereka adalah kelompok lansia kategori usia pertengahan (middle age). Rentang usia 45-59 tahun dipilih dikarenakan mayoritas wisatawan umrah Annisa Travel berada pada rentang umur tersebut.

Menurut Roscoe (dalam Sugiyono, 2012) jumlah sampel lebih dari 30 dan kurang dari 500 adalah tepat untuk semua riset dan jika sampel terbagi dalam beberapa sub sampel maka jumlah sampel minimum untuk setiap sub sampel adalah 30. Dalam penelitian ini, berhasil didapat sampel sebanyak 51 responden yang bersedia mengisi kuesioner yang disebarkan melalui Google Form.

\section{Temuan dan Pembahasan}

PT. Radian Kharisma Wisata atau lebih dikenal dengan Annisa Travel, didirikan di Jakarta pada tahun 2003, merupakan perusahaan swasta nasional yang bergerak dalam bidang Jasa Perjalanan. Annisa Travel berfokus pada tiga layanan, yaitu umrah, haji dan MICE and event organizer.

Adapun paket wisata religi yang disediakan oleh Annisa Travel yaitu:

- Paket Umrah Reguler

- Paket Umrah Awal Ramadhan

- Paket Umrah Akhir tahun

- Paket Umrah Plus 


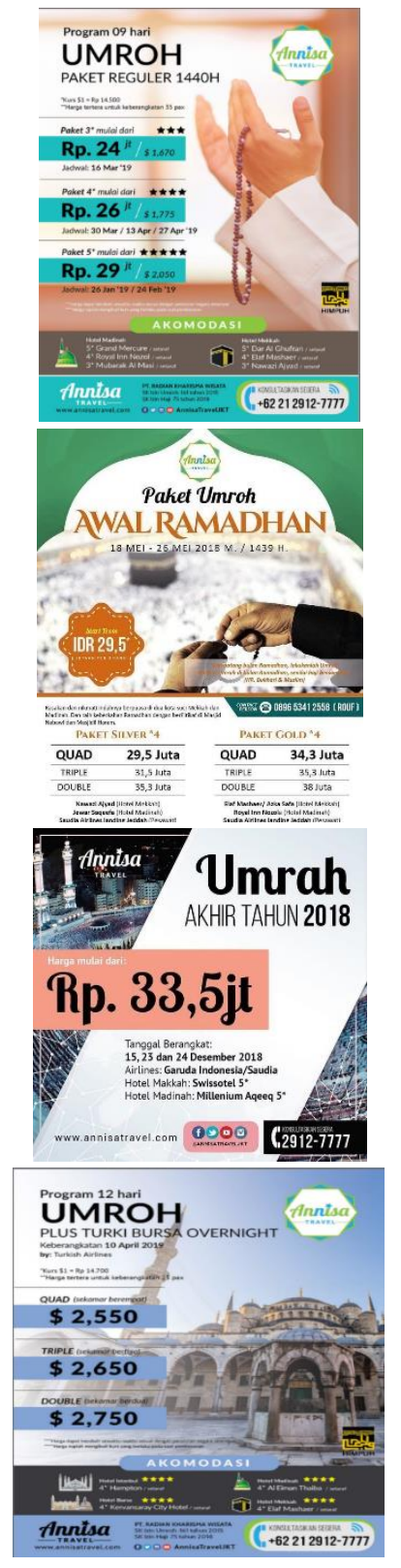

Gambar 4.1 Produk-produk paket umrah Annisa Travel

Analisis Data

Analisis deskriptif memberikan gambaran tentang data yang diperoleh. Gambaran data ini bisa menjadi acuan untuk melihat karakteristik data yang kita peroleh. Karakteristik data yang disajikan misalnya nilai rata-rata, minimum, maksimum dan standar deviasi. Berikut adalah gambaran umum berdasarkan data yang diperoleh.

\begin{tabular}{|c|c|c|c|c|c|c|c|}
\hline & \multicolumn{6}{|c|}{ Tabel 4.4 Analisis Deskriptif } & \multirow{3}{*}{$\begin{array}{c}\text { Std. } \\
\text { Deviation } \\
\text { Statistic }\end{array}$} \\
\hline & \multirow{2}{*}{\begin{tabular}{c|}
$\mathrm{N}$ \\
Statistic
\end{tabular}} & \multirow{2}{*}{\begin{tabular}{|l|} 
Range \\
Statistic
\end{tabular}} & \multirow{2}{*}{$\begin{array}{l}\text { Minimuum } \\
\text { Statistic }\end{array}$} & \multirow{2}{*}{\begin{tabular}{|l|} 
Maximu \\
$\mathrm{m}$ \\
Statistic \\
\end{tabular}} & \multicolumn{2}{|c|}{ Mean } & \\
\hline & & & & & Statistic & \begin{tabular}{|c|} 
Std. \\
Error \\
\end{tabular} & \\
\hline $\begin{array}{c}\text { Kualitas } \\
\text { Produk Wisata } \\
\text { (X) }\end{array}$ & 51 & 62.00 & 78.00 & 140.00 & $\begin{array}{l}114.39 \\
22 \\
\end{array}$ & \begin{tabular}{|l|}
2.0646 \\
6
\end{tabular} & 14.74460 \\
\hline $\begin{array}{c}\text { Minat } \\
\text { Kunjungan }(\mathrm{Y})\end{array}$ & 51 & 32.00 & 48.00 & 80.00 & $\begin{array}{l}66.451 \\
0\end{array}$ & \begin{tabular}{|l|}
1.2634 \\
6
\end{tabular} & 9.02289 \\
\hline $\begin{array}{l}\text { Valid N } \\
\text { (listwise) }\end{array}$ & 51 & & & & & & \\
\hline
\end{tabular}

Uji Validitas

Adapun dasar pengambilan keputusan dengan membandingkan nilai signifikansi dengan level of significant (5\%) adalah sebagai berikut:

a. Jika Signifikansi < 0.05 atau r-hitung > r-tabel maka Item Pertanyaan Valid.

b. Jika Signifikansi > 0.05 atau r-hitung < r-tabel maka Item Pertanyaan tidak Valid.

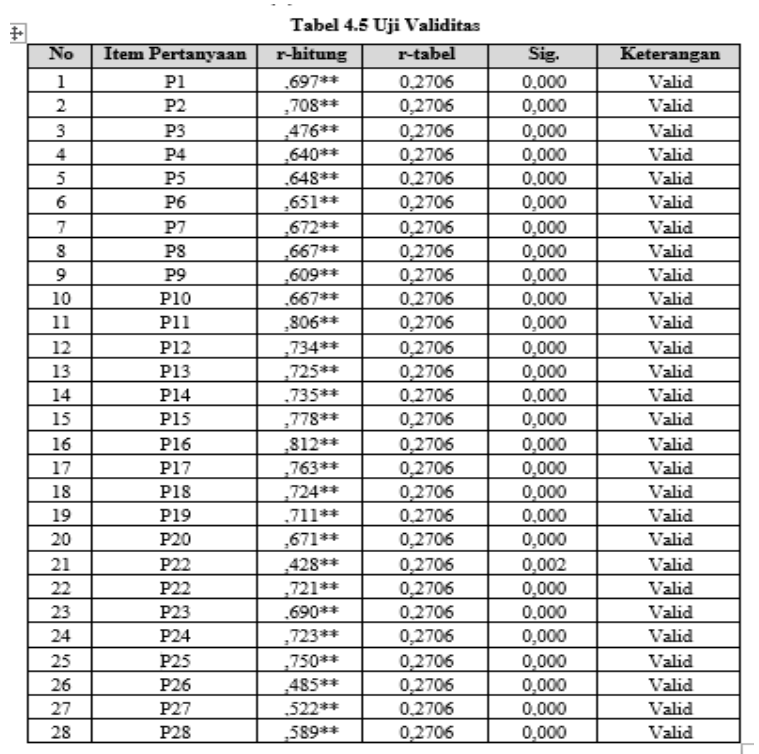

\begin{tabular}{|c|c|c|c|c|c|}
\hline No & Item Pertanyaan & r-hitung & r-tabel & Sig, & Keterangan \\
\hline 1 & P29 & $.743^{* *}$ & 0,2706 & 0,000 & Valid \\
\hline 2 & P30 &, $730^{* *}$ & 0,2706 & 0,000 & Valid \\
\hline 3 & P31 &, $715^{* *}$ & 0,2706 & 0,000 & Valid \\
\hline 4 & P32 &, $79^{* *}$ & 0,2706 & 0,000 & Valid \\
\hline 5 & P33 & $.835^{* *}$ & 0,2706 & 0,000 & Valid \\
\hline 6 & P34 &, $763^{* *}$ & 0,2706 & 0,000 & Valid \\
\hline 7 & P35 &, $748^{* *}$ & 0,2706 & 0,000 & Valid \\
\hline 8 & P36 &, $780^{* *}$ & 0,2706 & 0,000 & Valid \\
\hline 9 & P37 &, $754^{* *}$ & 0,2706 & 0,000 & Valid \\
\hline 10 & P38 & $.799^{* *}$ & 0,2706 & 0,000 & Valid \\
\hline 11 & P39 &, $739^{* *}$ & 0,2706 & 0,000 & Valid \\
\hline 12 & P40 &, $778^{* *}$ & 0,2706 & 0,000 & Valid \\
\hline 13 & P41 &, $737^{* *}$ & 0,2706 & 0,000 & Valid \\
\hline 14 & P42 & $.777^{* *}$ & 0,2706 & 0,000 & Valid \\
\hline 15 & P43 &, $632^{* *}$ & 0,2706 & 0,000 & Valid \\
\hline 16 & P44 & $.613^{* *}$ & 0,2706 & 0,000 & Valid \\
\hline
\end{tabular}


Uji Reliabilitas

Uji realiabilitas diperlukan untuk mengukur tingkat keandalan kuesioner. Untuk itu, dilakukan uji realiabilitas pada instrumen penelitian dengan menghitung nilai Cronbach Alpha. Dari hasil perhitungan kuesioner diperoleh hasil sebagai berikut:

a. Kualitas Produk Wisata (X)

Tabel 4.6 Uji Reliabilitas

Reliability Statistics

\begin{tabular}{|c|c|}
\hline $\begin{array}{c}\text { Cronbach's } \\
\text { Alpha }\end{array}$ & $\begin{array}{c}\text { N of } \\
\text { Items }\end{array}$ \\
\hline 952 & 28 \\
\hline
\end{tabular}

b. Minat Berkunjung (Y)

Reliability Statistics

\begin{tabular}{|r|r|}
\hline $\begin{array}{c}\text { Cronbach's } \\
\text { Alpha }\end{array}$ & N of ltems \\
\hline, 947 & 16 \\
\hline
\end{tabular}

Uji Linearitas

Kriteria pengambilan keputusan dengan uji linearitas yaitu :

a. Jika nilai Deviation from Linearity Sig. $>0,05$, maka ada hubungan yang linear secara signifikan antara variabel independent dengan variabel dependent.

b. Jika nilai Deviation from Linearity Sig. $<0,05$, maka tidak ada hubungan yang linear secara signifikan antara variabel independent dengan variabel dependent.

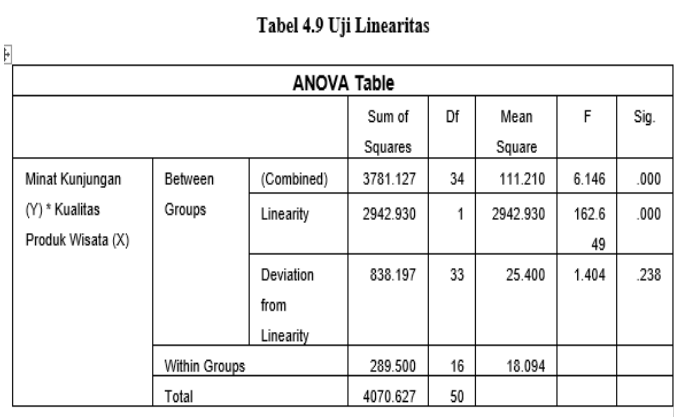

Analisis regresi sederhana

Adapun yang menjadi dasar pengambilan keputusan dalam analisis regresi dengan melihat nilai signifikansi (Sig.) hasil output SPSS yaitu:

a. Jika nilai signifikansi (sig.) lebih kecil < dari probabilitas 0,05 mengandung arti bahwa ada pengaruh kualitas produk wisata (X) terhadap minat kunjungan (Y)

b. Sebaliknya, jika nilai signifikansi (sig.) lebih besar > dari probabilitas 0,05 mengandung arti bahwa tidak ada pengaruh kualitas produk wisata (X) terhadap minat kunjungan $(\mathrm{Y})$.

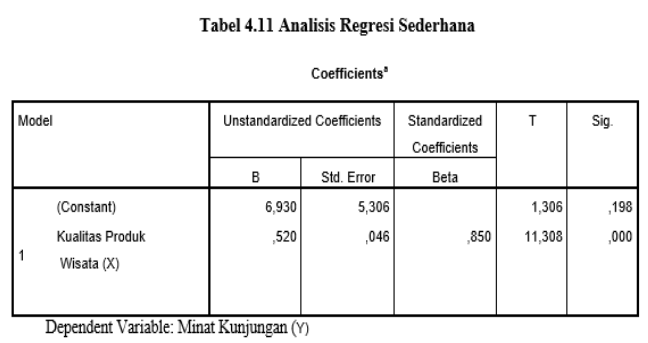

\section{Uji T (Uji Parsial)}

Uji $\mathrm{T}$ ini bertujuan untuk menguji apakah terdapat pengaruh parsial atau individu dari masing-masing variabel independen terhadap variabel dependen. Berikut adalah hasil perhitungan berdasarkan data yang diperoleh.

\section{Tabel 4.12 Uji T}

Coefficients $^{\mathrm{a}}$

\begin{tabular}{|c|c|c|c|c|c|c|}
\hline \multirow{2}{*}{\multicolumn{2}{|c|}{ Model }} & \multicolumn{2}{|c|}{$\begin{array}{l}\text { Unstandardized } \\
\text { Coefficients }\end{array}$} & \multirow{2}{*}{$\begin{array}{c}\text { Standardized } \\
\text { Coefficients } \\
\text { Beta }\end{array}$} & \multirow[t]{2}{*}{$\mathrm{T}$} & \multirow[t]{2}{*}{ Sig. } \\
\hline & & B & Std. Error & & & \\
\hline \multirow[t]{8}{*}{1} & (Constant) & 8.689 & 5.008 & & 1.735 & .090 \\
\hline & Atraksi & -.337 & .432 & -.094 & -.781 & .439 \\
\hline & Informasi & .504 & .364 & .141 & 1.384 & .173 \\
\hline & $\begin{array}{l}\text { Fasilitas } \\
\text { Umum }\end{array}$ & 1.345 & .412 & .384 & 3.261 & .002 \\
\hline & SDM & .970 & .446 & .288 & 2.175 & .035 \\
\hline & Pelayanan & .642 & .385 & .192 & 1.668 & .103 \\
\hline & Kebersihan & -.444 & .405 & -.123 & -1.098 & .279 \\
\hline & Aksesibilitas & .844 & .288 & .260 & 2.931 & .005 \\
\hline
\end{tabular}

Hipotesis 1: Tidak tolak Ho

Hipotesis 2: Tidak tolak Ho 
Hipotesis 3: Tidak tolak Ha

Hipotesis 4: Tidak tolak $\mathrm{Ha}$

Hipotesis 5: Tidak tolak H0

Hipotesis 6: Tidak tolak H0

Hipotesis 7: Tidak tolak Ha

\section{Uji F (Uji Simultan)}

Mengambil Keputusan (dengan nilai signifikansi)

a. Jika nilai signifikansi > dari pada 0,05 , maka $\mathrm{H} 0$ diterima dan $\mathrm{H} 1$ ditolak

b. Jika nilai signifikansi < daripada 0,05, maka $\mathrm{H} 0$ ditolak dan $\mathrm{H} 1$ diterima

Tabel 4.13 Uji F

\begin{tabular}{|l|l|l|r|r|c|}
\hline \multicolumn{7}{|c|}{ ANOVA $^{\mathbf{2}}$ Model } & $\begin{array}{c}\text { Sum of } \\
\text { Squares }\end{array}$ & Df & $\begin{array}{c}\text { Mean } \\
\text { Square }\end{array}$ & F \\
\hline \multirow{2}{*}{1} & Regression & 2942.930 & 1 & 2942.930 & 127.874 \\
\cline { 2 - 7 } & Residual & 1127.697 & 49 & 23.014 & \\
\cline { 2 - 7 } & Total & 4070.627 & 50 & & \\
\hline
\end{tabular}

a. Dependent Variable: Minat Kunjungan (Y)

b. Predictors: (Constant), Kualitas Produk Wisata (X0

\section{Pembahasan}

Berdasarkan hasil pengolahan data diperoleh kedua variabel yaitu kualitas produk wisata dan minat kunjungan. Karakteristik responden berdasarkan jenis kelamin di dominasi oleh wanita, untuk usia di dominasi oleh responden yang berusia 45 - 50 tahun, pendidikan di dominasi oleh $\mathrm{S} 1$, pekerjaan mayoritas sebagai pegawai swasta, responden yang menggunakan produk Annisa Travel mayoritas adalah responden yang baru pertama kali menggunakan produk tersebut.

Pada pengujian hipotesis terdapat dimensi yang berpengaruh dan tidak berpengaruh. Adapun dimensi yang berpengaruh yaitu, dimensi fasilitas umum, dimensi sumber daya manusia (SDM), dan dimensi aksesibilitas. Menurut Poerwanto (2004) kualitas produk wisata tergantung dari manusia, bahwa manusialah yang menciptakan fasilitas yang lengkap, aksesbilitas yang mudah dijangkau serta SDM yang ramah dan murah senyum. Hal ini dapat mendorong seseorang merasa puas dengan melakukan kunjungan. Oleh karena itu, dimensi fasilitas umum, sumber daya manusia (SDM) dan aksesibilitas sangat diperhatikan oleh wisatawan lansia sebelum melakukan perjalanan umrah. Pernyataan pada dimensi kualitas produk yang berpengaruh ini didukung oleh penelitian yang dilakukan oleh Kartika Dewi (2019) yang memperoleh hasil yang juga berpengaruh signifikan.

Sedangkan dimensi yang tidak berpengaruh meliputi dimensi atraksi, informasi, pelayanan dan kebersihan. Menurut Tantri (2018), motivasi lansia berwisata untuk memperoleh nilai keagamaan dan kehidupan yang lebih baik, serta mencari kebahagiaan. Sedangkan menurut Sulandari et.al (2009) motivasinya termasuk mengembangkan diri dan berkreasi sesuai minat mereka, melakukan sesuatu yang berarti untuk diri mereka sendiri dan orang lain. Tujuan utama mereka adalah meningkatkan keimanan dan ketakwaan mereka kepada Sang Pencipta. Oleh karena itu wisatawan lansia yang melakukan umrah tidak menjadikan atraksi, informasi, pelayanan serta kebersihan yang ditawarkan dalam produk Annisa Travel sebagai sesuatu yang dapat menghambat tujuan utama mereka. Dimensi yang tidak berpengaruh tersebut didukung oleh penelitian yang dilakukan oleh Ramadoni dan Rumorong (2019), yang juga memperoleh hasil yang signifikan tidak berpengaruh.

\section{Simpulan}

Berdasarkan pembahasan yang telah dijelaskan di bab sebelumnya mengenai pengaruh kualitas produk wisata religi umrah terhadap minat kunjungan 
wisatawan lansia di Annisa Travel Jakarta, maka diperoleh kesimpulan berikut:

Kualitas produk wisata memiliki tujuh dimensi, dengan nilai tertinggi adalah dimensi fasilitas umum, kemudian dimensi sumber daya manusia (SDM), lalu dimensi aksesibilitas. Sedangkan dimensi dengan nilai rendah yaitu, dimensi atraksi, selanjutnya dimensi kebersihan, kemudian dimensi informasi lalu dimensi pelayanan.

Kualitas produk wisata terbagi atas dimensi yang berpengaruh dan tidak berpengaruh. Dimensi yang tergolong berpengaruh adalah dimensi fasilitas umum, dimensi sumber daya manusia (SDM) dan dimensi aksesibilitas. Sedangkan yang tergolong dimensi tidak berpengaruh adalah dimensi atraksi, dimensi kebersihan, dimensi informasi dan dimensi pelayanan.

Dimana kualitas produk menjadi suatu dorongan kepada konsumen untuk membeli sebuah produk dalam jangka panjang. Ikatan seperti ini memungkinkan travel agen untuk memahami dengan saksama harapan serta kebutuhan dari wisatawan. Dengan demikian travel agen dapat meningkatkan minat kunjungan umrah. Kualitas produk wisata dapat menjadi peran utama dalam meningkatkan minat kunjungan yang maksimal dan dapat dipercaya.

Bagi pelaku wisata umrah, perlu untuk mempertahankan serta menjaga dimensi yang penting atau yang berpengaruh dari kualitas produk yaitu dimensi fasilitas umum, dimensi sumber daya manusia dan dimensi aksesibilitasnya.

\section{Referensi}

Amalina, D. 2017. Faktor Yang Mempengaruhi Proses Pengambilan Keputusan Wisatawan Berkunjung Ke Objek Wisata Religi Masjid Agung Islamic Centre Kabupaten Rokan Hulu. JOM Fisip, 4 (2).

Anwar, M. Hamid, D. Topowijono. 2017. Analisis Dampak Pengembangan Wisata Religi Makam Sunan Maulana Malik Ibrahim dalam Kehidupan Sosial Dan Ekonomi Masyarakat Sekitar (Studi Pada Kelurahan Gapurosukolilo Kabupaten Gresik). Jurnal Administrasi Bisnis, 44 (1).

Bodlender, J. et al. 1991. Developing Tourism Destination: Policy and Perspectives. Harow, Longman.

Buhalis, D. 2000. Marketing The Competitive Destination of The Future. Tourism Management, 21 (1).

Dewi, K. 2019. Pengaruh Produk Wisata Dan Kebijakan Harga Terhadap Minat Kunjungan Wisatawan. Media Wisata, 17 (2).

Hassan S, Zainal S, Mohamed $O$. 2015. Penentu Akuisisi Pengetahuan Tujuan dalam Wisata Religius: Perspektif Wisatawan Umrah. International Journal of Marketing Studies, 7 (3).

Holloway, J. dan Davidson, R. 2009. The Business of Tourism 8th Edition. England: Pearson Education Limited.

Kotler, P. 1997. Manajemen Pemasaran Edisi Bahasa Indonesia Jilid 2. Jakarta: PT Prenhallindo.

Munawar, A. Husin, S. dan Halim, A. 2003. Fikih Haji menuntun Jamaah Mencapai Haji Mabrur. Jakarta: Ciputat Press. 
Poerwanto. 2004. Analisis Kesan Wisatawan Terhadap Dimensi Kualitas Produk Wisata. Jurnal Ilmiah Pariwisata STP Trisakti, 9 (1).

Ramadoni, W. dan Rumorong, N. 2019. Pengaruh Kualitas Produk Wisata dan Harga Terhadap Minat Beli Wisatawan Ke Yogyakarta (Studi Kasus Pada Wisatawan Yang Menggunakan Jasa Pada CV Hosanna Global Partner). Jurnal Eksekutif, 16 (2).

Simamora, Bilson. 2002. Panduan Riset Prilaku Konsumen. Surabaya: Pustaka Utama.

Sugiyono, 2016. Metode Penelitian Kombinasi (Mixed Methods). Bandung: Alfabeta.

Sugiyono, 2012. Memahami Penelitian Kualitatif. Bandung: Alfabeta.

Sugiyono, 2012. Metode Penelitian Bisnis. Bandung : Alfabeta.

Sulandari, S. Martyastanti, D. dan Mutaqwarohmah, R. 2009. BentukBentuk Produktivitas Orang Lanjut Usia (Lansia). Jurnal Ilmiah Berskala Psikologi, 11 (1).

Tantri, E. 2018. Lanjut Usia (Lansia) Dalam Kebijakan Pariwisata Di Hong Kong (Tiongkok): Tahun 1978-2016. Jurnal Kajian Wilayah, 9 (2). 